\title{
17beta-hydroxysteroid dehydrogenase type 1 modulates breast cancer protein profile and impacts cell migration
}

\author{
Juliette A Aka ${ }^{1}$, Mouna Zerradi ${ }^{1}$, François Houle ${ }^{2}$, Jacques Huot ${ }^{2}$ and Sheng-Xiang Lin ${ }^{*}$
}

\begin{abstract}
Introduction: Human 17beta-hydroxysteroid dehydrogenase type 1 (17 $\beta$-HSD1) is a steroid-converting enzyme that has long been known to play critical roles in estradiol synthesis and more recently in dihydrotestosterone (DHT) inactivation, showing a dual function that promotes breast cancer cell proliferation. Previously, we reported the first observation of the influence of the enzyme on endogenous estrogen-responsive gene expression. Here, we demonstrate the impact of 173-HSD1 expression on the breast cancer cell proteome and investigate its role in cell migration.
\end{abstract}

Methods: $17 \beta-H S D 1$ was stably transfected in MCF7 cells and the proteome of the generated cells overexpressing 17 $\beta$-HSD1 (MCF7-17ßHSD1 cells) was compared to that of the wild type MCF7 cells. Proteomics study was performed using two-dimensional gel electrophoresis followed by mass spectrometry analysis of differentially expressed protein spots. Reverse transcription quantitative real-time PCR (RT-qPCR) was used to investigate the transcription of individual gene. The effect of 17ß-HSD1 on MCF7 cell migration was verified by a wound-healing assay.

Results: Proteomic data demonstrate that the expression of more than 59 proteins is modulated following $17 \beta$ HSD1 overexpression. 17 $\beta-H S D 1$ regulates the expression of important genes and proteins that are relevant to cell growth control, such as BRCA2 and CDKN1A interacting protein (BCCIP) and proliferating cell nuclear antigen (PCNA) which are down- and upregulated in MCF7-17ßHSD1 cells, respectively. RT-qPCR data reveal that 17ß-HSD1 increases the mRNA levels of estrogen receptors (ER) alpha and beta by 171 and 120\%, respectively, while decreasing that of the androgen receptor by $64 \%$. Interestingly, 17ß-HSD1 increases the mRNA transcript (by 3.6 times) and the protein expression of the metastasis suppressor gene nm23-H1 and the expression of the two enzymes are closely correlated. We have further shown that 17/-HSD1 expression is associated with an increase of MCF7 cell migration.

Conclusions: In addition to the regulation of important genes, we have demonstrated for the first time that $17 \beta$ HSD1 increases breast cancer cell migration, in spite of its positive regulation of the antimetastatic gene NM23. This is also correlated to its stimulation of breast cancer cell growth, further confirming its targeting in ER positive breast cancer. The novel findings in this study suggest several directions for future research on the contribution of $17 \beta-$ HSD 1 to breast cancer progression and related treatment.

\footnotetext{
*Correspondence: sheng-xiang.lin@crchul.ulaval.ca

${ }^{1}$ Laboratory of Molecular Endocrinology and Oncology, Centre Hospitalier

Universitaire de Québec Research Center (CHUQ - CHUL) and Department of Molecular Medicine, Laval University, 2705 boulevard Laurier, Québec G1V

4G2, Canada

Full list of author information is available at the end of the article
} 


\section{Introduction}

Breast cancer is the most frequent cancer affecting women. The malignancy accounts for about one in ten cancers in the world and is diagnosed in one million women each year $[1,2]$. In North America, breast cancer is the second most important cause of death from cancer in women, after lung cancer, and the leading cause of cancer death among those between 20 and 59 years of age $[3,4]$. After increasing through the $80 \mathrm{~s}$ and $90 \mathrm{~s}$, breast cancer incidence rates showed a welcome decrease of $3.5 \%$ per year from 2001 to 2004 and the mortality rate decreased by $1.9 \%$ per year in the United States between 1998 and 2006 [3,5]. This reflects an improvement in the diagnosis and treatment of the disease, yet it remains of prime importance.

Epidemiological evidence indicates that most breast cancer risk factors are associated with prolonged exposure of the mammary gland to high levels of estradiol (E2). This potent estrogen plays a crucial role in the development and evolution of hormone-dependent breast cancer [6]. About $60 \%$ of premenopausal and $75 \%$ of postmenopausal breast cancer patients show a hormone dependency [7]. The final steps of E2 biosynthesis implicate two principal pathways in breast cancer tissue: the aromatase pathway transforms androgens into estrogens, and the sulfatase pathway converts the inactive hormones estrone sulfate (E1S) and dehydroepiandrosterone sulfate (DHEA-S) into estrone (E1) and dehydroepiandrosterone (DHEA), respectively, via the action of steroid sulfatase (STS). Different enzymes further convert DHEA to $5 \alpha$-androstene- $3 \beta, 17 \beta$-diol (A-diol) and the latter to testosterone which can in turn be converted to E2 by aromatase. The inactive E1, synthesized by both STS and aromatase, is converted to the potent E2 by the action of reductive 17beta-hydroxysteroid dehydrogenases (17 $\beta$-HSDs) [8-10]. In breast cancer cells, E2 is principally synthesized by $17 \beta-$ HSD type 1 (17 $\beta$-HSD1), with the reduced form of nicotinamide adenine dinucleotide phosphate (NADPH) as a cofactor. Previously, we reported the dual function of $17 \beta-$ HSD1 in estradiol synthesis and dihydrotestosterone (DHT) inactivation stimulating cell proliferation [11]. Analyses of $17 \beta$-HSD 1 mRNA expression in breast carcinoma specimens from patients revealed that high expression of the enzyme correlates with a weak prognosis for breast cancer [12-14]. Despite these observations, the relationship between 17 $\beta$-HSD1 expression and that of genes and proteins involved in breast cancer cell growth has not been established. The aim of the present study was to investigate the impact of $17 \beta-\mathrm{HSD} 1$ overexpression on the protein profile of breast cancer cells. The MCF7 cell line is a human hormone-dependent breast cancer cell line widely used for breast cancer studies that expresses both estrogen and androgen receptors. Since the cell line barely expresses endogenous $17 \beta$ HSD1 $[11,15]$, we used it as cell model for the increase of $17 \beta-H S D 1$ expression. The proteomic approach using two-dimensional gel electrophoresis is the most popular tool to study global changes in protein profile following biological or chemical treatments. We thus used this technique to analyse the proteomic modification of MCF7 cells in response to $17 \beta$-HSD1 overexpression. Following the proteomics analysis, reverse transcription quantitative real-time PCR (RT-qPCR) was used to investigate the gene transcription of a number of differentially expressed proteins, such as proliferating cell nuclear antigen (PCNA) and the metastasis suppressor gene $\mathrm{nm} 23-\mathrm{H} 1$. The overexpression experiments, combined with further siRNA knockdown analysis, demonstrated a strong positive correlation between $\mathrm{nm} 23-\mathrm{H} 1$ regulation and $17 \beta-\mathrm{HSD} 1$ expression. We thus hypothesized that $17 \beta$-HSD1 could be implicated in breast cancer cell metastasis and evaluated its effect on MCF7 cell migration.

\section{Materials and methods}

\section{Cell culture and generation of stably-transfected MCF7- $17 \beta$ HSD1 cells}

Wild type (WT) MCF7 and T47D cells were cultured as previously described, with MCF7 cell culture medium containing $1 \mathrm{nM} \beta$-E2 [11]. Recombinant plasmid containing $17 \beta-$ HSD1 cDNA and the $17 \beta-$ HSD1 stably transfected-MCF7 cells (MCF7-17 $\beta$ HSD1 cells) were generated as previously described [11].

\section{Generation of protein extracts for proteomics analysis}

WT MCF7 and MCF7-17ßHSD1 cells were defrosted at the same time and cultured in flasks $\left(75 \mathrm{~cm}^{2}\right.$ growth area) in complete medium containing $\beta$-E2. After three passages, cells were seeded into $10 \mathrm{~cm}$ diameter dishes and cultured until reaching the desired confluence. For protein sample preparation, cells having reached 80 to 90\% confluence were washed twice with cold phosphatebuffered saline (PBS) and scraped with a rubber policeman in $1.2 \mathrm{~mL}$ PBS. Cells were collected in eppendorf tubes (Eppendorf, Mississauga, Ontario, Canada) and centrifuged at $3000 \mathrm{rpm}$ for 5 minutes. The cell pellets were re-suspended in $500 \mu \mathrm{L}$ lysis buffer T8 (7 M urea, $2 \mathrm{M}$ thiourea, 3\% CHAPS, $20 \mathrm{mM}$ DTT, $5 \mathrm{mM}$ TCEP, $0.5 \%$ IPG buffer $\mathrm{pH} 4-7,0.25 \%$ IPG buffer $\mathrm{pH} 3-10$ ) containing $50 \mathrm{mM}$ tris- $\mathrm{HCl} \mathrm{pH} 8.8,1 \mathrm{mM}$ phenylmethylsulfonyl fluoride (PMSF) and 1\% protease inhibitors cocktail (EMD Chemicals, Gibbs-town, NJ, USA). Protein samples were precipitated using the two-dimensional Clean-Up Kit (GE Healthcare, Piscataway, NJ, USA) and resolubilized in $\mathrm{T} 8$ buffer. The protein samples included three 
independent biological replicates (coming from three independent cell culture experiments), representing total proteins from each cell line (MCF7 and MCF7$17 \beta$ HSD1) for a total of six samples. The protein concentrations were determined using the two-dimensional Quant Kit (GE Healthcare, Piscataway, NJ, USA).

\section{Two-dimensional gel electrophoresis}

For the first dimension, $200 \mu \mathrm{g}$ total protein samples from MCF7 and MCF7-17 $\beta$ HSD1 cells were loaded onto 24-cm pH 4-7 immobilized pH gradient (IPG) strips (Immobiline DryStrips; GE Healthcare). Strips were rehydrated for 10 hours at 30 volts and isoelectric focusing was performed on an IPGphorII IEF system (GE Healthcare). For the second-dimension sodium dodecyl sulphate-polyacrylamide gel electrophoresis (SDS-PAGE), focused Immobiline DryStrips were equilibrated twice for 15 minutes in an equilibration buffer $(50 \mathrm{mM}$ tris- $\mathrm{HCl}$ $\mathrm{pH}$ 8.8, $6 \mathrm{M}$ urea, 30\% glycerol, 2\% SDS, trace of bromophenol blue) containing $10 \mathrm{mg} / \mathrm{mL}$ DTT for the first equilibration and $25 \mathrm{mg} / \mathrm{mL}$ iodoacetamide for the second one. Immobiline DryStrips were then transferred onto the surface of a $12 \%$ acrylamide gel $(20 \times 25 \times$ $0.1 \mathrm{~cm}$ ) and sealed using $0.5 \%$ agarose. Gels were run in an Ettan DALTtwelse system (GE Healthcare) in a standard tris-glycine SDS-PAGE buffer at $40 \mathrm{~mA} /$ gel and $15^{\circ} \mathrm{C}$ until the tracking dye reached the end of the gel. Three independent protein samples coming from three independent cell culture experiments were run for each cell line. Gels were fixed overnight in 40\% methanol, 7\% acetic acid, stained with Sypro Ruby (Invitrogen, Burlington, Ontario, Canada) and scanned with the ProXpress CCD scanner (PerkinElmer, Waltham, MA, USA). The two-dimensional gel electrophoresis was performed on the Proteomic Platform of the Infectious Disease Research Center (Québec, Canada).

\section{Two-dimensional gel image analysis}

Protein spot detection, spot matching and semiquantitative statistical analysis were performed using the Progenesis software version PG240 (Nonlinear Dynamics, Durham, NC, USA). For each cell line, three different gel images were analyzed and a corresponding synthetic image reference was obtained. After computer matching, detected spots and spot matches were manually edited for better accuracy. A spot had to be present in at least two of the three replicate gels to be considered in the analysis. The detection of protein spots differentially expressed was performed using the $t$-test $(P<0.05)$ and the Intelligent Noise Correction Algorithm (INCA) volume and proteins that were differentially expressed two-fold or higher were considered significant. Eighteen protein spots were selected among the differentially expressed spots and were excised from Sypro Rubystained two-dimensional gels using a ProXcision robot (PerkinElmer, Waltham, MA, USA) and sent for mass spectrometry (MS) analysis.

\section{Mass spectrometry and protein identification}

MS experiments were performed by the Proteomics Platform of the Eastern Quebec Genomics Center (Québec, Canada). Protein spots were washed with water and tryptic digestion was performed on a MassPrep liquidhandling robot (Waters, Milford, MA, USA) according to the manufacturer's specifications and the protocol of Shevchenko et al. [16], with the modifications suggested by Havlis et al. [17]. Peptide samples (aliquots of the digested protein samples) were separated by online reversed-phase (RP) nanoscale capillary liquid chromatography (nano LC) and analyzed by electrospray tandem mass spectrometry (ES-MS/MS). The experiments were performed with a Thermo Surveyor MS pump connected to an LTQ linear ion trap mass spectrometer (Thermo Fisher Scientific, San Jose, CA, USA) equipped with a nanoelectrospray ion source (Thermo Fisher Scientific). Peptide separation took place on a PicoFrit column BioBasic C18, $10 \mathrm{~cm} \times 0.075 \mathrm{~mm}$ internal diameter (New Objective, Woburn, MA, USA) with a linear gradient from 2 to $50 \%$ solvent $\mathrm{B}$ (acetonitrile, $0.1 \%$ formic acid) in 30 minutes, at $200 \mathrm{~nL} / \mathrm{min}$ (obtained by flow-splitting). Mass spectra were acquired using a data dependent acquisition mode using Xcalibur software version 2.0 (Thermo Fisher Scientific). Each full scan mass spectrum (400 to $2000 \mathrm{~m} / \mathrm{z}$ ) was followed by collision-induced dissociation of the seven most intense ions. The dynamic exclusion (30 seconds exclusion duration) function was enabled, and the relative collisional fragmentation energy was set to $35 \%$.

All MS/MS samples were analyzed using the Mascot algorithm (Matrix Science, London, UK; version Mascot) and the Uniref100_14_0_Homo_sapiens_9606 database (version with 89892 entries). Mascot was searched with a fragment ion mass tolerance of $0.50 \mathrm{Da}$ and a parent ion tolerance of 2.0 Da. Iodoacetamide derivative of cysteine was specified as a fixed modification and oxidation of methionine was specified as a variable modification. Two missed cleavages were allowed.

Scaffold (version Scaffold_2_01_02, Proteome Software Inc., Portland, OR, USA) was used to validate MS/MSbased peptide and protein identifications. The protein identification cut off was set at a confidence level of 95\% (Mascot score > 33) with at least two peptides matching to a protein. Proteins that contained similar peptides and could not be differentiated based on MS/ MS analysis alone were grouped to satisfy the principles of parsimony. 


\section{Reverse transcription quantitative real-time PCR and semiquantitative RT-PCR}

Total RNA was isolated from cells using Trizol Reagent (Invitrogen, Burlington, Ontario, Canada) in 6-well plates and treated with DNase 1. Analysis of the RNA integrities using the Bioanalyzer 2100 (Agilent Technologies, Mississauga, Ontario, Canada) and the RNA 6000 Nano Chips (Agilent Technologies, Mississauga, Ontario, Canada) showed good qualities for all the RNA samples with RNA integrity numbers (RIN) higher than $8 / 10$. RNA samples for RT-qPCR analyses comprised two biological repetitions for each condition and cell line. For each sample, mRNA quantifications were performed twice as previously described [11,18] with Atp5o, Hprt1 and G6PD genes used as internal controls. The procedures were performed at the Q_RTPCR Platform service at CHUQ-CHUL Research Center (Quebec, Canada). The primers used for the amplification and the corresponding cDNA fragments of each mRNA are shown in Additional file 1. The mRNA levels were expressed as mRNA copies/ $\mu \mathrm{g}$ total RNA.

Semiquantitative RT-PCR was carried out and analyzed as previously described [11] except for the number of cycles, which was 30 .

\section{siRNA synthesis and transfection}

The sense and antisense sequences of three 17 $\beta$-HSD1 siRNAs were selected and synthesized as previously described [11]. Transfection of T47D cells with siRNA was carried out in 6-well plates using Lipofectamine siRNAMax (Invitrogen), 3x10 cells/well and $200 \mathrm{nM}$ mixed $17 \beta$-HSD1-specific siRNAs.

For cell migration assays, MCF7-17 $\beta$ HSD1 cells were transfected with $100 \mathrm{nM}$ mixed $17 \beta$-HSD1-specific siRNAs in $3.5 \mathrm{~cm}$ diameter dishes. Control cells were transfected with scramble (control) siRNA [11].

\section{Cell migration assay}

Cell migration was evaluated by using a wound-healing assay. First, MCF7 and MCF7-17ßHSD1 cells were cultivated in $75 \mathrm{~cm}^{2}$ culture flasks in complete growth medium. Cells, at low passage number, were seeded at high density into $3.5 \mathrm{~cm}$ diameter dishes in E2-free medium containing $5 \%$ fetal bovine serum (FBS). Two days later, straight scratches were made in triplicate across confluent monolayer cultures using a p200 micropipette tip. Thereafter, cells were washed five times with fresh E2-free medium and were incubated in the same medium. Second, MCF7-17 $\beta$ HSD1 cells were transfected with $17 \beta-H S D 1-$ specific siRNAs or scramble siRNA (control siRNA) in $3.5 \mathrm{~cm}$ diameter dishes in complete growth medium, and were incubated. Forty-eight hours after transfection, a wound was created by manually scraping the cell monolayer as described above. Cells were then washed five times and incubated in E2-free medium containing 5\%
FBS. All experiments were done in quadruplicate. The movements of cells in the scratched area were monitored by capturing images every 15 minutes for a total duration of 48 hours using the $\times 10$ objective lens of a phase-contrast microscope. The scratch widths were measured at specific time points using the NIH ImageJ software.

\section{Western blot}

WT MCF7 and MCF7-17 $\beta$ HSD1 cells were cultured in complete medium containing $\beta$-E2 and total proteins were extracted from cells with complete T8 lysis buffer. Equal volumes of proteins were separated by $12 \%$ SDS-PAGE and then electro-blotted onto nitrocellulose membranes. The membranes were blocked with $5 \%$ non-fat milk in PBS-tween 20 (PBS-T) for one hour at room temperature. After blocking, the membranes were incubated for two hours at room temperature in 5\% non-fat milk in PBS-T containing the following primary antibodies against the indicated proteins: $17 \beta$-HSD1 (1:100,000 dilution of ab51045) from Abcam (Cambridge, MA, USA), PCNA (1:500 dilution of sc-7907), $\mathrm{nm} 23-\mathrm{H} 1$ (1:500 dilution of sc343), BCCIP (1:300 dilution of SC-130898) from Santa Cruz Biotechnology (Santa Cruz, CA, USA), and $\beta$-actin as the internal control $(1: 7,500$ dilution of a monoclonal antibody, from Sigma). Next, membranes were incubated for one hour at room temperature with a horseradish peroxidase-conjugated secondary antibody (Santa Cruz Biotechnology) diluted 10,000 times. Protein signals were visualized with Chemiluminescence Reagent (PerkinElmer) and bands were quantified using the NIH ImageJ software. The ratios between the signals of the protein of interest and $\beta$-actin were calculated to determine the relative protein expression values.

\section{Results \\ Overexpression of $17 \beta$-HSD1 modulates the protein profile of MCF7 cells}

To investigate the proteomic modifications of MCF7 cells in response to $17 \beta$-HSD1 overexpression, we performed two-dimensional gel analysis using total protein lysates of the WT breast cancer cell line MCF7 and MCF7 cells overexpressing $17 \beta$-HSD1 cultured in medium containing E2. We then compared the proteomic profile of the two cell lines. To do so, we first stably transfected WT MCF7 cells with a $17 \beta$-HSD1 plasmid to generate the $17 \beta$-HSD1 stably transfected cells (MCF7-17 $\beta$ HSD1 cells). Western blot showed an increase in $17 \beta$-HSD1 expression in the MCF7-17 $\beta$ HSD1 cells (Figure 1A). Proteomic analyses were carried out on six two-dimensional electrophoresis gels made from three independent biological repetitions of protein samples from MCF7-17ßHSD1 cells and the parent cells. The two cell lines displayed similar spot patterns (Figure 1B) which allowed a good spot alignment for the proteome comparison. MCF7-17 $\beta$ HSD1 protein samples 
A

MCF7 MCF7-17ßHSD1

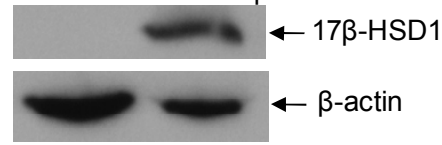

B

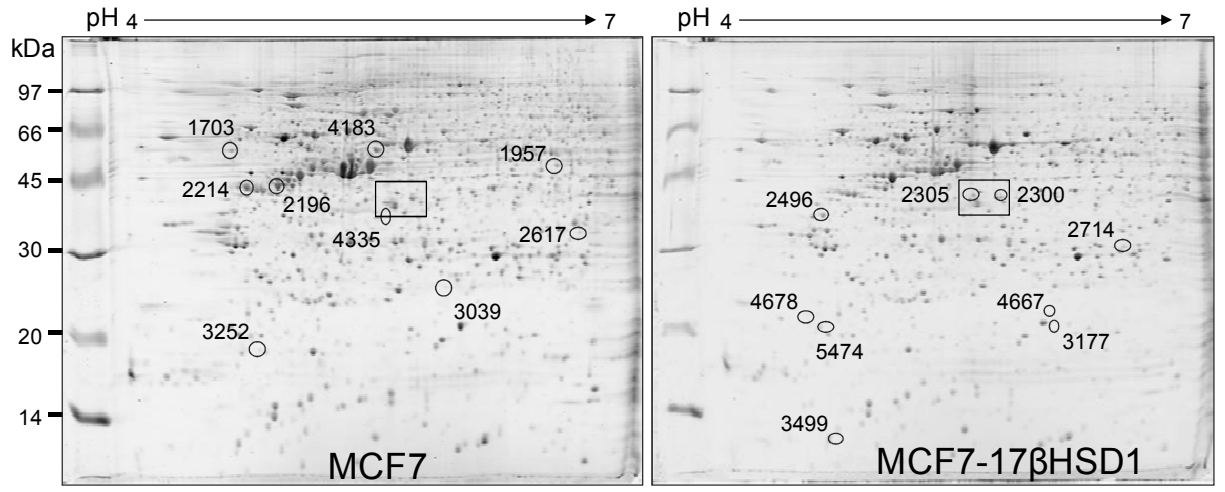

C

\begin{tabular}{|c|c|c|c|c|c|c|}
\hline & \multicolumn{3}{|c|}{ 2-D gel image analysis } & \multicolumn{3}{|c|}{ Mass spectrometry analysis } \\
\hline & $\begin{array}{c}\text { Total } \\
\text { number } \\
\text { spots }\end{array}$ & $\begin{array}{l}\text { Variant } \\
\text { spots } \\
(>2 \text {-fold })\end{array}$ & $\begin{array}{c}\text { Number } \\
\text { of unique } \\
\text { spots }\end{array}$ & $\begin{array}{l}\text { Spots } \\
\text { picked } \\
\text { for MS }\end{array}$ & $\begin{array}{l}\text { Proteins } \\
\text { identified }\end{array}$ & $\begin{array}{l}\text { Distinct } \\
\text { proteins }\end{array}$ \\
\hline \multirow[t]{2}{*}{ MCF7 } & 3132 & & 7 & 4 (unique) & 18 & 15 \\
\hline & & 18 (5 down, 13 up) & & 9 (variant) & 42 & 35 \\
\hline $\begin{array}{c}\text { MCF7- } \\
\text { 17ßHSD1 }\end{array}$ & 3024 & & 5 & 5 (unique) & 13 & 9 \\
\hline
\end{tabular}

D

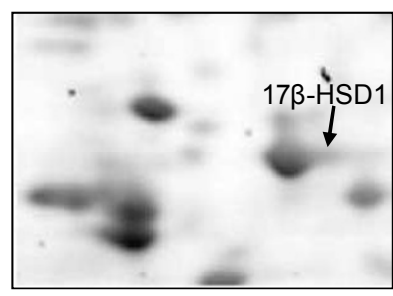

MCF7

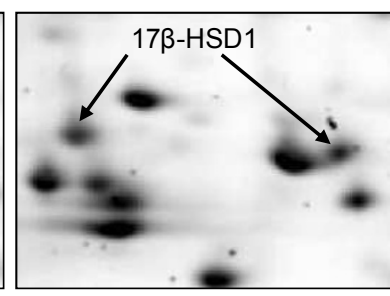

MCF7-17ßHSD1

Figure 1 Proteomic analysis of wild type (WT) MCF7 cells and MCF7 cells stably transfected with 17 $\beta$-HSD1 (MCF7-17ßHSD1). (A) 17beta-hydroxysteroid dehydrogenase type $1(\mathbf{1 7} \beta$-HSD1) and $\beta$-actin expression between WT MCF7 and MCF7-17 $\beta$ HSD1 revealed by western blots. (B) Representative two-dimensional gel images for WT MCF7 and MCF7-17ßHSD1 cells. Whole cell lysates (200 $\mu \mathrm{g})$ from each cell were separated by two-dimensional electrophoresis and visualized by Sypro Ruby staining. The two-dimensional gels were scanned and the differentially expressed (2-fold or higher, $P<0.05)$ proteins were detected using Progenesis software. The 18 differentially expressed protein spots that were selected for mass spectrometry (MS) analysis are marked with circles. Protein spots upregulated in MCF7-173HSD1 are depicted in the MCF7-17ßHSD1 proteome image; protein spots downregulated in MCF7-17ßHSD1 are depicted in the MCF7 proteome image. The numbers refer to the spot number listed in Table 1 and Additional file 2. The squares represent the indicated area shown in more detail in (D). (C) Summary of the numbers of spots and proteins obtained from the proteomics data. *Upregulated (up) and downregulated (down) proteins in MCF7-17ßHSD1 as compared to WT MCF7 cells. (D) Zoom showing some differentially expressed protein spots from WT MCF7 and MCF7$17 \beta \mathrm{HSD} 1$ comparison. Arrows indicate $17 \beta-\mathrm{HSD} 1$ protein which was revealed by MS analysis to be present in the spot numbers 2,305 (unique to MCF7-17 $\beta$ HSD1) and 2,300 (upregulated in MCF7-17ßHSD1 as compared to WT MCF7 cells). 
exhibited a lower number of protein spots $(3,024)$ than MCF7 (3,132 spots). The proteomic analyses using the Progenesis software and a $t$-test (with a $P$-value $<0.05$ ) identified 30 significant differential protein spots between MCF7 and MCF7-17ßHSD1 as follows: 5 spots downregulated and 13 spots upregulated in MCF7-17ßHSD1 as compared to MCF7, for a total of 18 spots that varied 2fold or more, while 7 and 5 spots were unique to MCF7 and MCF7-17ßHSD1 samples, respectively (Figure 1C).

The analyses by MS of 18 protein spots (Figure 1B), selected among the differentially expressed spots, allowed the identification of proteins with a known UniProt accession number among all the spots for a total of 73 proteins. The numbers of proteins found in each cell line are listed in Figure 1C. Some spots contained more than one protein and some proteins were present in more than one spot. For example, $17 \beta$-HSD1 was identified in the spot numbers 2,300 and 2,305 (Figure 1B and 1D). This resulted in the identification of 59 distinct proteins distributed as follows: 15 and 9 proteins from spots unique to MCF7 and MCF7-17 $\beta$ HSD1 respectively, and 35 proteins from spots upregulated in either cell line. These results showed that $17 \beta-$ HSD1 modulates protein profile in MCF7 cells.

Using the UniProt database [19], we determined the subcellular locations and functions (or biological processes) of each of the 59 proteins identified by MS analysis. The original spot for each protein, the spot fold-increase or fold-decrease in one cell line versus another cell line, the protein name, the molecular mass, the isoelectric point, the number of unique peptides allowing the protein identification in the MS analysis, and the UniProt accession number of the protein are listed (Table 1; see Additional file 2 for additional data). The information about the molecular function and/or biological process was found for most proteins. Important proteins involved in cell proliferation were differentially expressed following $17 \beta-H S D 1$ overexpression. These proteins include PCNA, peroxiredoxin 2, BRCA2 and CDKN1A interacting protein (BCCIP) and ribonuclease/angiogenin inhibitor 1 (RNH1). Intriguingly, the metastasis inhibition factor nm23 (nm23$\mathrm{H1}$ ), an enzyme known to act as a downregulator of breast cancer metastasis, was upregulated by $17 \beta-$ HSD1 and found in a spot unique to MCF7-17 $\beta$ HSD1 as compared to MCF7. The repartitions of the functions and subcellular locations of the 59 differentially expressed proteins are illustrated and the percentages of proteins involved in each molecular function and found in each cellular location are indicated (Figure 2). Overexpression of $17 \beta-\mathrm{HSD} 1$ in MCF7 cells causes a differential expression of proteins that act mainly in metabolism (5.5\% upregulated protein and $5.5 \%$ repressed), mRNA processing (3.1\% induced and $7.9 \%$ repressed), protein biosynthesis (9\%) and transport
(8\%). Differentially expressed proteins are mainly located in the cytoplasm and nucleus.

In order to verify the differential expression of individual proteins in MCF7 and MCF7-17 $\beta$ HSD1, we performed western blot analysis on total protein extracts for three of the identified proteins, PCNA, nm23-H1 and BCCIP. The differential expression of PCNA and nm23-H1 in MCF7 and MCF7-17 $\beta$ HSD1 was confirmed. However, BCCIP barely exhibited a protein band and thus, the observed relative protein expression values in the two cell lines should be considered with caution (Figure 3A and $3 \mathrm{~B})$.

\section{The mRNA levels of enzymes involved in cell proliferation are regulated by $17 \beta-$ HSD 1}

Next, we investigated if $17 \beta$-HSD1 influences the transcription of genes involved in cell proliferation. To do this, six proteins involved in cell proliferation, cancerogenesis or metastasis regulation were selected: PCNA, peroxiredoxin 2, nm23-H1, S-phase kinase-associated protein 1 (SKP1), BCCIP and RNH1. Their mRNA levels were measured by RT-qPCR analysis of total RNA extracts from MCF7 and MCF7-17ßHSD1 cell lines (Table 2). The increases in mRNA levels of PCNA, peroxiredoxin 2, nm23-H1 and BCCIP following 17 $\beta$-HSD1 overexpression were significant (more than 2 -fold). The most regulated mRNA is that of nm23-H1 which was 3.6-fold higher in MCF7-17 $\beta$ HSD1 cells than in MCF7 cells (Table 2).

We further evaluated the correlation between mRNA and protein levels by comparing data from the RT-qPCR and the proteomic analyses. Proteomics and RT-qPCR data were considered to correlate if the mRNA level and protein spots were regulated in the same direction. It must be noted that the observed correlations are semiquantitative, since two-dimensional gel data are considered semiquantitative, and some spots contained more than one protein. In addition, some proteins were found in several spots, which can be the effect of post-translational modifications [20]. When comparing MCF7-17ßHSD1 to MCF7, we found that $\mathrm{RNH} 1$, a regulator of angiogenesis, was downregulated at both protein and transcript levels, whereas PCNA, SKP1 and nm23-H1 were upregulated at both protein and transcript levels. With the exception of peroxiredoxin-2 (which is an anti-apoptosis protein) and BCCIP (a promoter of cell cycle arrest), all the other four proteins for which the mRNA expression was evaluated exhibited regulation in the same direction for protein and mRNA in MCF7$17 \beta$ HSD1 as compared to MCF7 (Table 2). These data can indicate the existence of a semiquantitative correlation between protein and mRNA expression. Thus, it may be possible to predict the presence of a protein based on its gene expression or inversely. However, as suggested in a previous study [21], the correlation between mRNA and 
Table 1 Mass spectrometry identification of proteins differentially expressed between wild type MCF7 cells and MCF7 cells stably transfected with $17 \beta-H S D 1$ (MCF7-17 $\beta$ HSD1).

\begin{tabular}{|c|c|c|c|c|c|c|c|}
\hline Spot & FC & Description & $\begin{array}{l}\text { UniProt } \\
\text { number }\end{array}$ & $\begin{array}{l}\text { MW } \\
\text { exp/ } \\
\text { pred }\end{array}$ & $\begin{array}{l}\text { pl } \\
\exp \end{array}$ & Pep & Function and/or biological process \\
\hline \multicolumn{8}{|c|}{ Spot downregulated in MCF7-17ßHSD1 as compared to WT MCF7 } \\
\hline \multirow[t]{2}{*}{4183} & 2.7 & Cathepsin D & P07339 & $28 / 45$ & 5.0 & 20 & $\begin{array}{l}\text { Proteolysis, pathogenesis of diseases (breast } \\
\text { cancer) }\end{array}$ \\
\hline & & $\begin{array}{l}\text { Ezrin-radixin-moesin-binding phosphoprotein } \\
50\end{array}$ & 014745 & $58 / 39$ & 5.3 & 17 & Wnt signaling pathway \\
\hline 3252 & 2.3 & Neudesin & Q9UMX5 & $19 / 19$ & 4.7 & 2 & Neuronal differentiation and proliferation \\
\hline \multirow[t]{3}{*}{1703} & 2.2 & $\begin{array}{l}\text { Ribonuclease/angiogenin inhibitor } 1 \text { (RNH1) } \\
(3177)^{a}\end{array}$ & P13489 & $58 / 50$ & 4.6 & 24 & Regulation of angiogenesis, mRNA catabolism \\
\hline & & $\begin{array}{l}\text { BRCA2 and CDKN1A interacting protein } \\
(B C C I P)^{\mathrm{a}}\end{array}$ & Q9P287 & $58 / 36$ & 4.6 & 4 & Promote cell cycle arrest \\
\hline & & Cell division cycle protein 123 homolog & O75794 & $58 / 39$ & 4.6 & 2 & Required for S phase entry of the cell cycle \\
\hline \multicolumn{8}{|c|}{ Spot unique to WT MCF7 } \\
\hline \multirow[t]{4}{*}{2617} & $U$ & Poly(rC)-binding protein 2 & Q15366 & $32 / 39$ & 6.4 & 11 & RNA binding \\
\hline & & Purine nucleoside phosphorylase & P00491 & $32 / 32$ & 6.4 & 6 & DNA modification \\
\hline & & BTB/POZ domain-containing protein KCTD15 & Q96SI1 & $32 / 32$ & 6.4 & 4 & Potassium ion transport \\
\hline & & RING finger protein 114 & Q9Y508 & $32 / 26$ & 6.4 & 2 & Cell differentiation \\
\hline \multirow[t]{3}{*}{4335} & U & Peptidyl-prolyl cis-trans isomerase $\mathrm{E}$ & Q9UNP9 & $35 / 33$ & 5.4 & 10 & Protein folding, mRNA splicing \\
\hline & & Transgelin-2 & P37802 & $20 / 22$ & 5.6 & 8 & Muscle development \\
\hline & & Splicing factor, arginine/serine-rich 2 & Q01130 & $35 / 25$ & 5.4 & 2 & mRNA processing \\
\hline \multirow[t]{3}{*}{3039} & U & RAB11B protein & A5YM50 & $24 / 25$ & 5.7 & 11 & Protein transport, signal transduction \\
\hline & & Peroxiredoxin- $2^{a}$ & P32119 & $24 / 22$ & 5.7 & 6 & $\begin{array}{l}\text { Cell redox regulation, anti- } \\
\text { apoptosis }\end{array}$ \\
\hline & & Splicing factor, arginine/serine-rich 3 & P84103 & 24/19 & 5.7 & 2 & RNA processing in relation with cell proliferation \\
\hline \multicolumn{8}{|c|}{ Spot upregulated in MCF7-17BHSD1 as compared to WT MCF7 } \\
\hline \multirow[t]{4}{*}{2714} & 2.5 & Exosome complex exonuclease RRP41 & Q9NPD3 & $29 / 26$ & 6.2 & 3 & rRNA processing \\
\hline & & Enoyl-CoA hydratase, mitochondrial & P30084 & $29 / 31$ & 6.2 & 6 & Fatty acid and lipid metabolism \\
\hline & & Heat shock 70 kDa protein 1 & P08107 & $29 / 70$ & 6.2 & 5 & Stress response \\
\hline & & Eukaryotic translation initiation factor $4 \mathrm{H}$ & Q15056 & $29 / 27$ & 6.2 & 4 & Host-virus interaction, protein biosynthesis \\
\hline 2496 & 4.9 & Proliferating cell nuclear antigen $(\mathrm{PCNA})^{\mathrm{a}}$ & P12004 & $32 / 29$ & 4.6 & 16 & DNA replication \\
\hline 5474 & 4.0 & $\begin{array}{l}\text { Myosin regulatory light chain 2, } \\
\text { nonsarcomeric }\end{array}$ & P19105 & $20 / 20$ & 4.7 & 5 & Cytokinesis, receptor capping, cell locomotion \\
\hline 2300 & 3.3 & 605 acidic ribosomal protein $\mathrm{PO}_{(2305)}$ & A8K4Z4 & $40 / 34$ & 5.6 & 6 & Ribosome biogenesis, translation elongation \\
\hline \multicolumn{8}{|c|}{ Spot unique to MCF7-17BHSD1 } \\
\hline 2305 & $U$ & $\begin{array}{l}\text { 17/-hydroxysteroid dehydrogenase type } 1 \\
(2300)\end{array}$ & P14061 & $41 / 35$ & 5.4 & 22 & Steroid biosynthesis \\
\hline 3177 & U & Metastasis inhibition factor nm23 $(\mathrm{nm} 23-\mathrm{H} 1)^{a}$ & P15531 & $21 / 17$ & 5.9 & 6 & $\begin{array}{l}\text { Cell cycle and proliferation, } \\
\text { nucleotide metabolism }\end{array}$ \\
\hline 4667 & U & $60 S$ ribosomal protein L11 & P62913 & $21 / 20$ & 5.9 & 2 & Binds to $5 S$ ribosomal RNA \\
\hline 4678 & U & S-phase kinase-associated protein 1 (SKP1) ${ }^{a}$ & P63208 & $20 / 19$ & 4.6 & 2 & Ubl conjugation pathway \\
\hline
\end{tabular}

The function and/or biological process were obtained from the UniProt database [19].

Spot, spot number; FC, fold change; $U$, unique; MW, molecular weight (kDa); pl exp, isoelectric point as determined from the two-dimensional gel experiments;

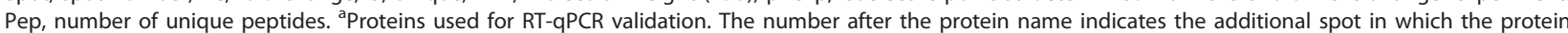
was found.

protein levels may not be sufficient to predict protein expression levels from quantitative mRNA data.

Transcription of various genes involved in E2 production Because $17 \beta$-HSD1 is a pivotal enzyme in the synthesis of E2, a hormonal steroid playing a major role in breast cancer induction and progression, we were interested to know if its overexpression in MCF7 cells would influence the expression of other genes involved in the hormone synthesis, inactivation and action. The mRNA levels of these proteins, which include $17 \beta$-HSDs type 2 (17 $\beta$-HSD2), type 5 (17 $\beta$-HSD5), type 7 (17 $\beta$-HSD7), type 12 (17 $\beta$-HSD12), aromatase (or P450arom), estrogen sulfotransferase (EST), STS, androgen receptor 


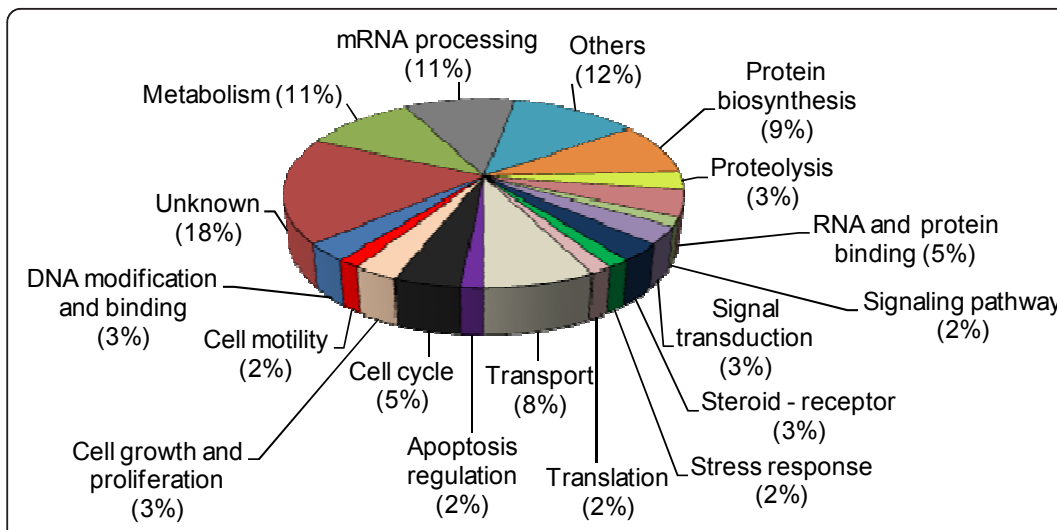

Functional category

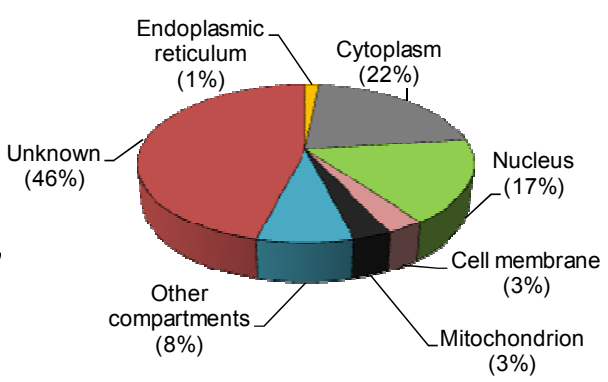

Cellular location

Figure 2 Functions and cellular locations of the differentially expressed proteins between wild type MCF7 cells and MCF7 cells stably transfected with 17 $\beta$-HSD1 (MCF7-17ßHSD1). The Uniprot database [19] was used to generate the cellular location and the molecular function and/or biological process of each of the 59 nonredundant (distinct) proteins identified by mass spectrometry analysis as differentially regulated. Of the 59 distinct proteins, the percentages of proteins involved in each molecular function and found in each cellular location are indicated in brackets.

(AR), estrogen receptor alpha $(\mathrm{ER} \alpha)$ and estrogen receptor beta $(\mathrm{ER} \beta)$, were quantified by RT-qPCR (Figure $3 \mathrm{C})$. RT-qPCR analyses revealed that the overexpression of $17 \beta$-HSD1 in MCF7 cells induces an increase in the mRNA expression of $17 \beta$-HSD5, STS, $17 \beta$-HSD12 and ER $\beta$ by 20, 33, 73 and $120 \%$, respectively, while inhibiting AR expression by 64\%. The highest mRNA-level modulation was observed with $\mathrm{ER} \alpha$, which exhibited a significant increase of $171 \%$. The increase in $17 \beta-$ HSD7 was small, whereas no modulation was observed with $17 \beta$-HSD2 and aromatase expression (Figure $3 \mathrm{C}$ and $3 \mathrm{D})$. These results show that the expression of $17 \beta-$ HSD1 can influence that of other genes implicated in estradiol metabolism and action, especially the estrogen receptors (ER), and further confirm the enzyme role in producing active estrogen and inactivation of DHT [11].

\section{Correlation between $17 \beta-\mathrm{HSD} 1$ and $\mathrm{nm} 23-\mathrm{H} 1$ expression}

Since our proteomic and RT-qPCR data showed that $17 \beta$-HSD1 overexpression increases the metastasis inhibition factor nm23-H1 mRNA and protein levels, we were interested to know if $17 \beta$-HSD1 knockdown would decrease nm23-H1 expression. T47D cells were chosen for this investigation because the cell line expresses a high level of endogenous $17 \beta-$ HSD1 $[11,15,22]$. Cells were transfected with $17 \beta$-HSD1-specific siRNA and with scramble siRNA (control siRNA) and total RNA was extracted 48 hours after transfection. The $17 \beta-\mathrm{HSD} 1$ and $\mathrm{nm} 23-\mathrm{H} 1 \mathrm{mRNAs}$ were quantified by RT-qPCR. The efficacy of $17 \beta-$ HSD 1 knockdown by its specific siRNA was demonstrated since $92 \%$ inhibition of $17 \beta-$ HSD1 mRNA was observed
(Figure 3E). Nm23-H1 mRNA levels were compared in control-siRNA- and 17 $\beta$-HSD1-siRNA-transfected T47D cells. A decrease of $31 \%$ of nm23-H1 mRNA expression was observed after $17 \beta$-HSD1 gene knockdown (Figure $3 F)$. These results, combined with proteomic and RTqPCR analyses of MCF7 and MCF7-17ßHSD1, indicate a positive correlation between $17 \beta-\mathrm{HSD} 1$ and nm23-H1 expression.

\section{Regulation of cell migration by $17 \beta-$ HSD 1}

To investigate if $17 \beta$-HSD1 could have any implication in cancer metastasis, we evaluated the effect of its expression on MCF7 cell migration by means of a wound-healing assay. The migrations of WT MCF7 and MCF7-17 $\beta$ HSD1 cells were first compared. We found that cell migration was higher in MCF7-17 $\beta$ HSD1 stably overexpressing $17 \beta-\mathrm{HSD} 1$ than in WT MCF7 cells, showing that MCF7-17 $\beta$ HSD1 cells have more ability to invade a scratch than WT MCF7 cells (Figure 4A and $4 B)$. The effect of $17 \beta$-HSD1 knockdown on cell migration was then tested in MCF7-17 $\beta$ HSD1 cells transfected with $17 \beta$-HSD1-specific siRNAs or control siRNA. Semiquantitative RT-PCR analysis showed a 98\% decrease of $17 \beta$-HSD1 mRNA after transfection of MCF7-17ßHSD1 cells with specific siRNAs as compared to the control cells (Figure 4C). Importantly, the knockdown of 17 $\beta$-HSD1 in MCF7-17 $\beta$ HSD1 cells was associated with a decreased cell migration (by $16.1 \%, P<$ $0.05)$ compared to cells transfected with control siRNA (Figure $4 \mathrm{D}$ and $4 \mathrm{E}$ ). Taken together, these results show that $17 \beta$-HSD1 expression is positively correlated with MCF7 cell migration. 
C

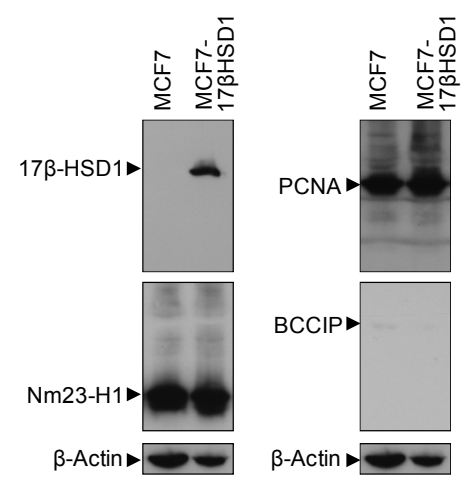

B

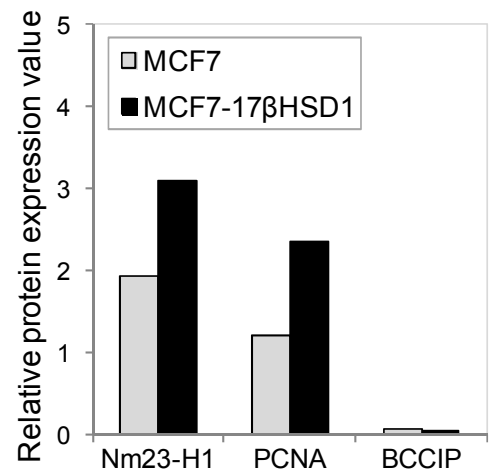

$\mathbf{E}$

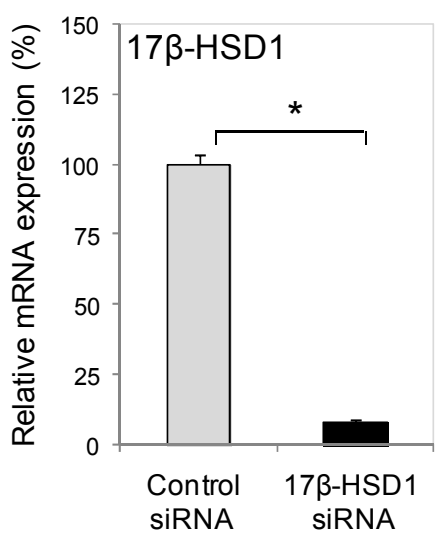

D

$\mathbf{F}$
RT-qPCR values (mRNA copies/ $\mu$ g total RNA)

\begin{tabular}{|c|c|c|}
\hline Description & MCF7 & MCF7-17ßHSD1 \\
\hline $17 \beta-H S D 2$ & $\mathrm{~N}$ & $\mathrm{~N}$ \\
\hline 17ß-HSD5 & 850,141 & $1,019,716$ \\
\hline 17ß-HSD7 & 158,578 & 182,812 \\
\hline 17ß-HSD12 & 101,488 & 175,265 \\
\hline Aromatase (P450arom) & $\mathrm{N}$ & $\mathrm{N}$ \\
\hline Estrogen sulfotransferase (ES & 0 & \\
\hline Steroid sulfatase (STS) & 80,284 & 107,927 \\
\hline Estrogen receptor alpha (ERa) & 652,621 & $1,770,663$ \\
\hline Estrogen receptor beta ( $E$ & 7,430 & 16,380 \\
\hline Androgen receptor (AR) & 95,889 & 34,189 \\
\hline
\end{tabular}
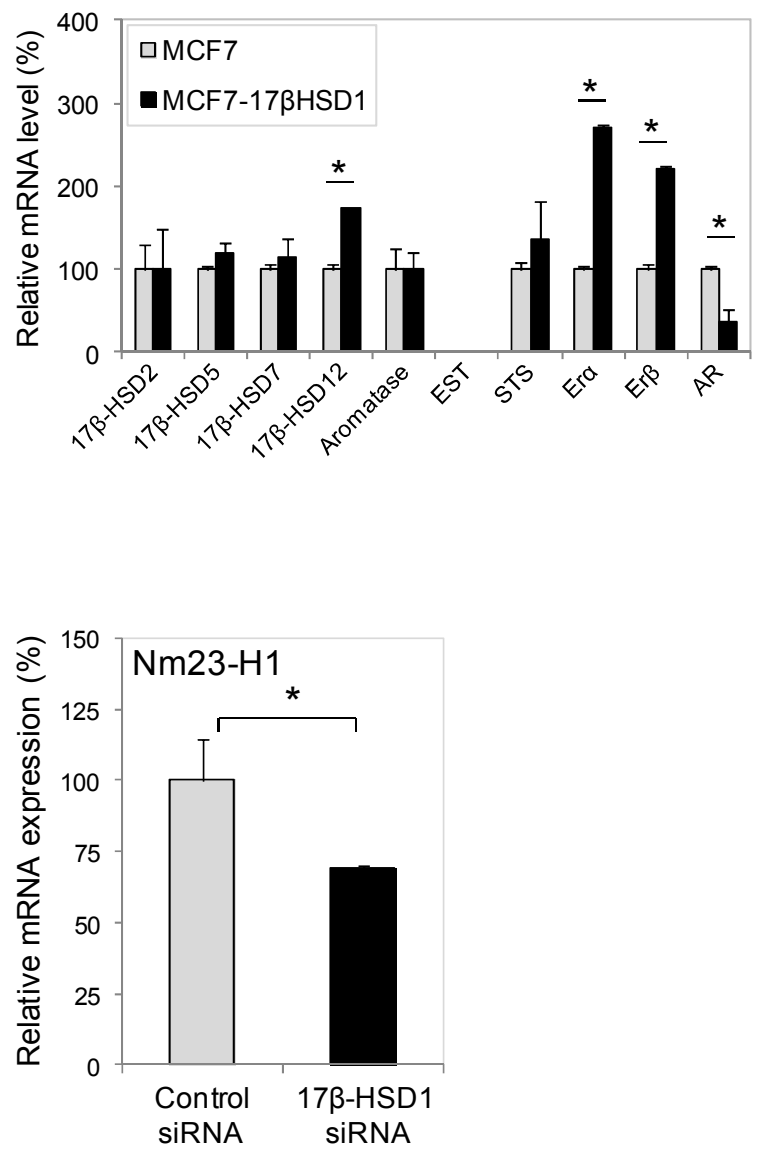

Figure 3 mRNA and protein level modulation by 17beta-hydroxysteroid dehydrogenase type 1 (17 $\beta$-HSD1). (A) Expression of 17 $\beta$-HSD1, proliferating cell nuclear antigen (PCNA), nm23-H1, and BRCA2 and CDKN1A interacting protein (BCCIP) in wild type (WT) MCF7 cells and MCF7 cells stably transfected with 17 $\beta$-HSD1 (MCF7-17 $\beta$ HSD1) revealed by western blots. $\beta$-actin protein amount was used as internal control. The arrows show the positions of the protein bands. (B) The western blot bands in (A) were quantified, and the ratio between the protein signals of interest and the $\beta$-actin signal was calculated to determine the relative protein expression values for WT MCF7 and MCF7-17 $\beta$ HSD1. (C) Reverse transcription quantitative real-time polymerase chain reaction (RT-qPCR) values (mRNA copies/ug total RNA) of mRNAs encoding proteins involved in estradiol production and/or action in WT MCF7 and MCF7-173HSD1. N, negligible (RT-qPCR values $<1,000$ ); 0, mRNA not detected after many rounds of amplification. (D) Relative mRNA expression values of enzymes involved in estradiol production in MCF7-17ßHSD1 as compared to WT MCF7. The mRNA levels in WT MCF7 cells were fixed at 100. (E) and (F) Relative 17ß-HSD1 (E) and nm23-H1 (F) mRNA expression in siRNA-transfected T47D cells. T47D cells were transfected with 17R-HSD1 siRNA or control siRNA and 17B-HSD1 mRNA was quantified by RT-qPCR. mRNA quantity in control-siRNA transfected cells was fixed at 100 . Error bars represent standard deviation. ${ }^{*} P<0.05$ analyzed by Student's t-test. 
Table 2 mRNA quantification by RT-qPCR of genes involved in breast cancer cell proliferation within wild type MCF7 and MCF7 cells stably transfected with 17 $\beta$-HSD1 (MCF7-17ßHSD1) and comparison with two-dimensional gel data.

\begin{tabular}{|c|c|c|c|c|}
\hline Description $^{a}$ & MCF7 & MCF7-17ßHSD1 & $\begin{array}{l}\text { Fold } \\
\text { regulation }\end{array}$ & $\begin{array}{l}\text { Correlation } \\
\text { 2-D gel and } \\
\text { RT-qPCR }\end{array}$ \\
\hline \multicolumn{5}{|c|}{ RT-qPCR value (mRNA copies/ug total RNA) } \\
\hline Proliferating cell nuclear antigen (PCNA) & $1,599,813$ & $4,483,982$ & +2.8 & Yes $^{c}$ \\
\hline Peroxiredoxin 2 & $4,078,760$ & $8,585,424$ & +2.1 & $\mathrm{No}^{c}$ \\
\hline Metastasis inhibition factor nm23 (nm23-H1) & $5,366,763$ & $19,356,416$ & +3.6 & Yes $^{c}$ \\
\hline S-phase kinase-associated protein 1 (SKP1) & $3,810,452$ & $5,714,509$ & +1.5 & Yes \\
\hline BRCA2 and CDKN1A interacting protein (BCCIP) & 345,839 & $1,074,647$ & +3.1 & $\mathrm{No}^{\mathrm{c}}$ \\
\hline Ribonuclease/angiogenin inhibitor 1 (RNH1) & $1,015,193$ & 727,425 & -1.4 & Yes $^{c}$ \\
\hline
\end{tabular}

Standard deviations were $<10 \%$ of duplicates.

${ }^{\text {a }}$ proteins were selected for reverse transcription quantitative real-time polymerase chain reaction (RT-qPCR) after their identification by mass spectrometry analysis of two-dimensional (2-D) gel protein spots.

${ }^{b}$ Fold regulation of mRNA levels in MCF7 cells stably transfected with 17 $\beta$-HSD1 (MCF7-17 $\beta$ HSD1) compared to wild type MCF7 cells; +, fold increase; -, fold decrease).

${ }^{\mathrm{C}}$ Mass spectrometry analysis showed that the two-dimensional spot contained several proteins including the indicated protein.

\section{Discussion}

\section{Proteomic modifications of MCF7 cells in response to 17ß-HSD1 overexpression}

In a previous study, we showed that modulating the expression of the steroid-converting enzyme 17 $\beta$-HSD1 in MCF7 and T47D cells led to a differential cell growth compared to the parent cells, cultured in medium containing E2 [11]. The present study compared the proteomes of the stably transfected MCF7-17ßHSD1 and WT MCF7 cells and established the first differential profile of a cell line overexpressing the enzyme and its parent cell. Our proteomics data revealed that increasing $17 \beta$-HSD1 expression significantly modulates the expression of proteins involved in various functional activities such as cell cycle, cell growth, apoptosis and carcinogenesis. Examples include PCNA, BCCIP and peroxiredoxin-2. Considering the functions of these enzymes in breast cancer, the directions in which their expression is regulated by $17 \beta-$ HSD1 agree with its role in increasing breast cancer cell growth. This can reveal the factors that make $17 \beta$-HSD1 stably-transfected MCF7 cells grow faster than the WT MCF7 cells when cultured in medium containing E2 [11]. The four most represented functional activities for the modulated proteins are metabolism (examples include alpha- $\mathrm{N}$-acetylgalactosaminidase and mitochondrial enoyl-CoA hydratase), mRNA processing (eukaryotic initiation factor 4A-III and arginine/serine-rich splicing factor 2), protein biosynthesis (elongation factor 1-gamma) and transport (endoplasmic reticulum resident protein ERp29 and RAB11B protein) (Figure 2, Table 1 and Additional file 2). The predominant locations of differentially expressed proteins in the nucleus and cytoplasm might reflect their functions in mRNA processing and protein biosynthesis. These four functions are known to be essential in steroid signalling which involves fast nongenomic activities (including the transport and metabolism of signalling molecules) and genomic mechanisms mediated by their specific receptors; these later mechanisms comprise gene transcription (RNA formation and mRNA processing) and protein biosynthesis [14] related to cell growth and regulation. The presence of E2 in MCF7 and MCF7-17ßHSD cell culture medium and the change in expression of a large number of proteins involved in these four functions following $17 \beta$-HSD1 overexpression suggest a modulation of E2 effects by $17 \beta$ HSD1. In fact, $17 \beta-H S D$ enzymes fit well into the concept of pre-receptor regulation of steroid action as they efficiently alter the binding of steroids to their genomic and nongenomic receptors and effectors, acting as a metabolic switch prior to the function of these receptors [14]. The concept of pre-receptor regulation of E2 action by $17 \beta$ HSD1 corroborates with its effect on the modulation of E2 responsiveness of pS2 genes in T47D cells [11], since E2 exerts its biological effect on breast cancer predominantly via the mediation of ER $\alpha$ and ER $\beta[23,24]$. The strong stimulation of ER $\alpha$ (171\% increase) and ER $\beta$ (120\% increase) gene expression and the protein regulation of a large number of non-estrogen-responsive genes caused by $17 \beta-\mathrm{HSD} 1$ overexpression further suggest that the ligand-independent transcriptions of ER target genes are also modulated by the enzyme. Indeed, this stimulation can influence the regulation of gene transcription by ER.

A recent study showed a high level of $17 \beta-$ HSD2 in the WT MCF7 cell line [25]. Our data, on the contrary, showed negligible expression of $17 \beta-$ HSD2 in this cell line, in conformity with other studies $[15,26]$. While $17 \beta$-HSD1 has no effect on the expression of the E2inactivating enzyme $17 \beta-\mathrm{HSD} 2$, it increases the mRNA levels of the E2-producing enzymes $17 \beta$-HSDs type 5, 7 and 12 , with type 12 having a significant, and the highest increase. This suggests a concerted action of reductive $17 \beta$-HSDs to accelerate the cellular E2 biosynthesis. 
A

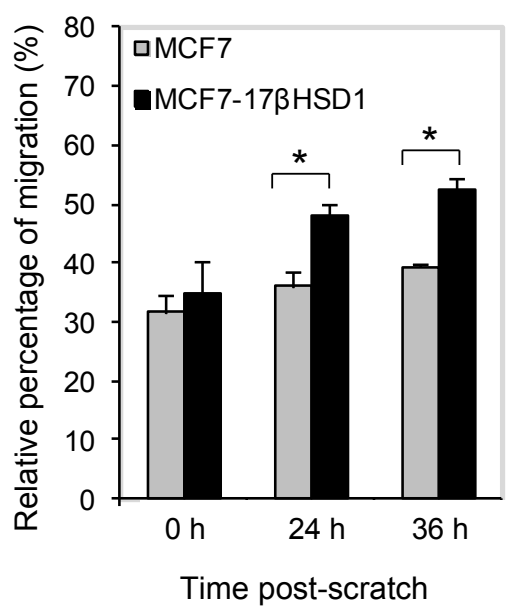

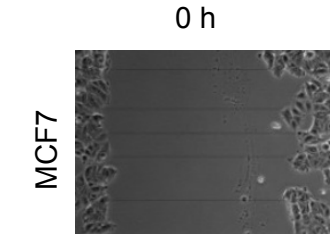
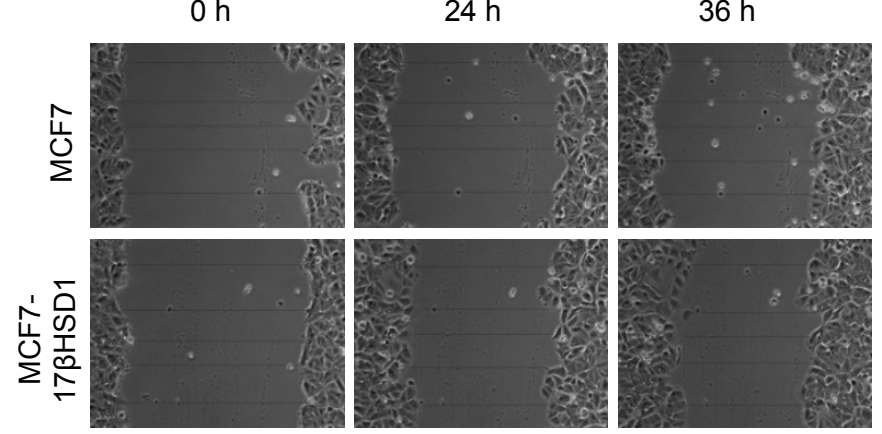

C

D

$\mathbf{E}$
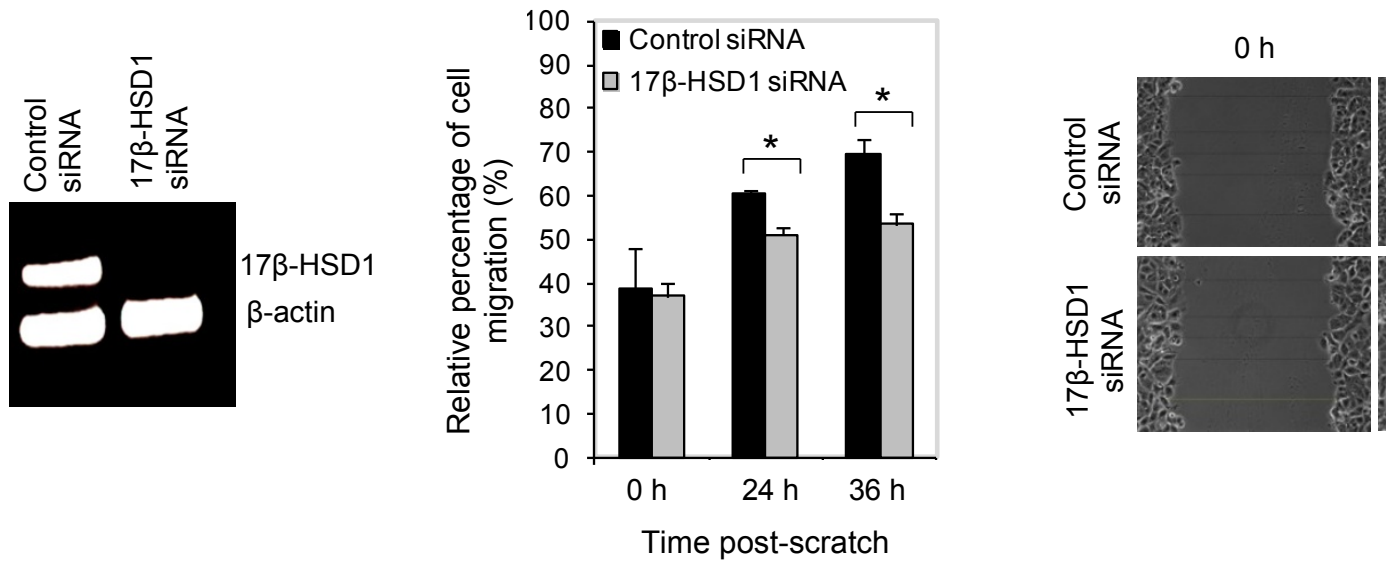

$36 \mathrm{~h}$

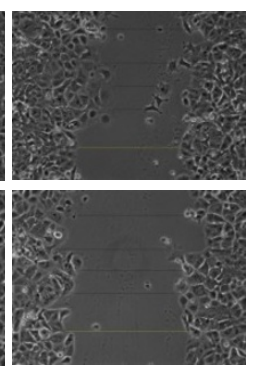

Figure 4 17beta-hydroxysteroid dehydrogenase type 1 (17 $\beta$-HSD1) is a positive regulator of MCF7 cell migration. (A) and (B) Comparison of cell migration between wild type (WT) MCF7 and MCF7 cells stably transfected with 17 $\beta$-HSD1 (MCF7-17 3 HSD1). A scratch was applied to WT MCF7 and MCF7-17קHSD1 cells confluent in dishes (3.5 cm diameter) and the ability to invade the scratch was measured. (A) The relative migration of WT MCF7 and MCF7-17קHSD1 cells at 24 and 36 hours post-scratch was quantified. The scratch widths, two near the border and three in the middle of the scratch (as shown in $\mathbf{B}$ ) were measured at the indicated time points using the $\mathrm{NIH}$ ImageJ software and data were used to calculate the percentage of migration. (B) Results showed that WT MCF7 cells have less ability to invade the scratch than the MCF7-17קHSD1 cells. Lines represent measurements made to assess modifications in scratch widths. (C) 17ß-HSD1 knockdown by siRNA in MCF7-17 $\beta$ HSD1 cells. Semiquantitative reverse transcription polymerase chain reaction (RT-PCR) was performed using $17 \beta$-HSD1 and $\beta$-actin

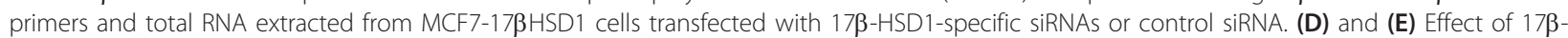

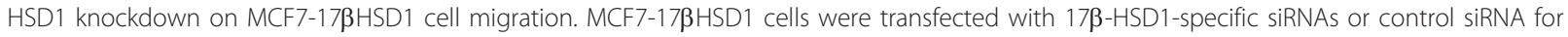
48 hours before creating a wound by scraping the cell monolayer. Cells transfected with 17ß-HSD1 siRNA have less ability to invade the scratch than cells transfected with control siRNA. All experiments were done in quadruplicate, and representative images of cell progression in the scratch are shown. Error bars represent standard deviation. ${ }^{*} P<0.05$ analyzed by Student's $t$-test.

\section{Breast cancer cell migration is increased by $17 \beta-$ HSD1} despite a positive correlation with the metastasis suppressor gene $\mathrm{nm} 23-\mathrm{H} 1$

Two estrogen-responsive genes involved in metastasis regulation, cathepsin $\mathrm{D}$ (Table 1) [27] and $\mathrm{nm} 23-\mathrm{H} 1$ [28-30], were found to be differentially expressed at the protein levels following $17 \beta$-HSD1 overexpression.
Cathepsin D, an independent marker of poor prognosis in breast cancer that correlates with the incidence of clinical metastasis [31], was downregulated. Nm23-H1 was upregulated at the protein level, its mRNA increased 3.6-fold with $17 \beta$-HSD1 overexpression (in MCF7-17 $\beta$ HSD1), and its gene expression decreased by $31 \%$ following $17 \beta$-HSD1 knockdown in T47D. These 
results demonstrate that $17 \beta-\mathrm{HSD} 1$ expression is positively and closely correlated to $\mathrm{nm} 23-\mathrm{H} 1$ expression. The downregulation of cathepsin $\mathrm{D}$ can be related to the increase of nm23-H1 as their negative correlation has already been demonstrated [27]. Patients with malignant melanoma who develop metastases during the first two years after diagnosis have significantly lower levels of tumor $\mathrm{nm} 23-\mathrm{H} 1$ expression (56\% of the mean value) compared to patients with less aggressive disease (164\%) [32]. The nm23-H1 gene, NM23, is known to function as a tumor metastasis suppressor gene and its transcript level is reduced in highly metastatic cells [32,33]. It has been reported that $\mathrm{nm} 23-\mathrm{H} 1$ inhibits cell migration and cancer metastasis by modulating the activity of Rhofamily small GTPase enzymes, which are known to play a key role in the actin cytoskeleton dynamics required for cancer cell migration and invasion [34]. In agreement with the strong enhancement of nm23-H1 mRNA level by $17 \beta$-HSD1, we hypothesized the implication of $17 \beta-H S D 1$ in tumor metastasis. Until now, quantitative analyses of the transcripts of estrogen-producing enzymes in breast cancer metastases have not demonstrated any significant association between $17 \beta-$ HSD1 mRNA level and metastases, although the sulfatase and aromatase mRNA levels were significantly associated with the presence of metastases in some studies [35-37]. Using the wound-healing assay, we demonstrated for the first time that increasing $17 \beta-\mathrm{HSD} 1$ expression led to the increase of MCF7 cell migration while $17 \beta-$ HSD1 knockdown decreased MCF7 cell migration. Our study thus shows for the first time that $17 \beta-H S D 1$ expression is positively correlated with the migration of the breast cancer cell line MCF7, revealing its role as a positive regulator of cell migration, contrary to $\mathrm{nm} 23-\mathrm{H} 1$.

E2-induced time-dependent increases in the abundance of nm23-H1 mRNA and protein are coincident with the expression level of its receptor ER $\alpha$ [29], which has been shown to interact with the non-metastasis gene nm23-H1 $[27,29]$. Since our cell models were cultivated in the presence of E2 and our data showed that $17 \beta-H S D 1$ positively regulates ER $\alpha$ mRNA level, one could postulate that the positive correlation between $\mathrm{nm} 23-\mathrm{H} 1$ and $17 \beta-\mathrm{HSD} 1$ expression is coincident with the activation of nm23- $\mathrm{H} 1$ expression by ER $\alpha$ and E2, which are increased with $17 \beta$ HSD1 expression. Thus, $17 \beta$-HSD1 may indirectly affect $\mathrm{nm} 23-\mathrm{H} 1$ expression via $\mathrm{ER} \alpha$ action. On the other hand, the increase of MCF7 cell migration by $17 \beta-$ HSD1, demonstrated in the present study, corroborates with its role in stimulating breast cancer cell growth [11] and the poor prognosis for patients in whom $17 \beta-\mathrm{HSD} 1$ is highly expressed in the breast [13]. This may open a new study on the role of this multifunctional steroid enzyme, that appeared early in evolution [38,39], revealing a complex mechanism in breast cancer with its expression. The latter may involve protein-protein and protein-DNA interactions among ER $\alpha, N M 23,17 \beta-H S D 1, A R$, cathepsin D and other genes and proteins. The role of $17 \beta-\mathrm{HSD} 1$ is in keeping with evidence from recent studies $[22,40]$.

\section{Conclusions}

Our study demonstrates that $17 \beta$-HSD1 affects breast cancer cell proteome and modulates expression of several genes at both mRNA and protein levels. Among the individual mRNA and proteins for which the regulation was investigated, the most strongly modulated by $17 \beta$ HSD1 are ER $\alpha$ and $n m 23-H 1$. Intriguing observations are that although $17 \beta$-HSD1 strongly stimulates nm23$\mathrm{H} 1$ expression, it is associated with an increased MCF7 cell migration. Here, we report the general study of proteomics with $17 \beta-\mathrm{HSD} 1$ expression modification, while the mechanism on cell migration modification opens a new study of interest for additional roles of the wellknown steroid-converting enzyme. It can be of great interest to investigate $17 \beta-\mathrm{HSD} 1$ role in cancer metastasis formation.

\section{Additional material}

Additional file 1: Table showing the primers used for reverse transcription quantitative real-time polymerase chain reaction. Additional file 2: Table of additional data for mass spectrometry identification of proteins differentially expressed between wild type MCF7 and MCF7 stably transfected with 17 $\beta$-HSD1 (MCF717ßHSD1).

\section{Abbreviations}

AR: androgen receptor; BCCIP: BRCA2 and CDKN1A interacting protein; $17 \beta-$ HSD1: 17beta-hydroxysteroid dehydrogenase type 1; CHAPS: 3-[(3-

cholamidopropyl)dimethylammonio]-1-propanesulfonate; cm: centimeter; $\mathrm{cm}^{2}$ : square centimeter; DHEA: dehydroepiandrosterone; DHEA-S: dehydroepiandrosterone sulfate; DHT: dihydrotestosterone; E1: estrone; E1S: estrone sulphate; E2: estradiol; ER: estrogen receptor; ERa: estrogen receptor alpha; ERß: estrogen receptor beta; ES-MS/MS: electrospray tandem mass spectrometry; EST: estrogen sulfotransferase; FBS: fetal bovine serum; IPG: immobilized pH gradient; INCA: Intelligent Noise Correction Algorithm; MS: mass spectrometry; nano LC: nanoscale capillary liquid chromatography; NADPH: the reduced form of nicotinamide adenine dinucleotide phosphate; PBS: phosphate-buffered saline; PBS-T: PBS-tween 20; PCNA: proliferating cell nuclear antigen; PMSF: phenylmethylsulfonyl fluoride; RIN: RNA integrity number; RNH1: ribonuclease/angiogenin inhibitor 1; RP: reversed-phase; RT$P C R$ : reverse transcription polymerase chain reaction; $R T-q P C R$ : reverse transcription quantitative real-time polymerase chain reaction; SDS-PAGE: sodium dodecyl sulphate-polyacrylamide gel electrophoresis; SKP1: S-phase kinase-associated protein 1; STS: steroid sulfatase; WT: wild type.

\section{Acknowledgements}

We thank Mrs G Racine for her advices in two-dimensional gel image analysis; we acknowledge Dr E-L Calvo, CHUQ Research Center (Quebec, Canada), for his critical reading of the manuscript. We thank Ms S Méthot for her valuable editing of the manuscript. This work was supported by the Canadian Institutes of Health Research, with a grant to S-X Lin (Principal Investigator for FRN57892). 


\section{Author details}

'Laboratory of Molecular Endocrinology and Oncology, Centre Hospitalier Universitaire de Québec Research Center (CHUQ - CHUL) and Department of Molecular Medicine, Laval University, 2705 boulevard Laurier, Québec G1V 4G2, Canada. ${ }^{2}$ Cancer Research Center of Laval University and Centre Hospitalier Universitaire de Québec Research Center (CHUQ - L'Hôtel-Dieu de Québec), 9 rue McMahon, Québec G1R 2J6, Canada.

\section{Authors' contributions}

JAA, MZ and FH carried out the experimental studies. JAA and SXL designed the study. JAA, JH and SXL prepared the manuscript. All authors read and approved the final manuscript.

\section{Competing interests}

The authors declare that they have no competing interests.

Received: 25 July 2011 Revised: 10 May 2012 Accepted: 12 June 2012 Published: 12 June 2012

\section{References}

1. Sasco AJ: Breast Cancer and the Environment. Horm Res 2003, 60(Suppl 3):50.

2. ESHRE Capri Workshop Group: Hormones and breast cancer. Hum Reprod Update 2004, 10:281-293

3. Jemal A, Siegel R, Ward E, Hao Y, Xu J, Murray T, Thun MJ: Cancer statistics, 2008. CA Cancer J Clin 2008, 58:71-96.

4. Canadian Cancer Society's Steering Committee: Canadian Cancer Statistics 2009. Toronto: Canadian Cancer Society; 2009 [http://www.cancer.ca/ statistiques]

5. American Cancer Society: Breast cancer facts \& figures 2009-2010. Atlanta: American Cancer Society, Inc; 2009 [http://www.cancer.org].

6. Russo $\mathrm{H}$, Russo J: Role of hormones in mammary cancer initiation and progression. J Mammary Gland Biol Neoplasia 1998, 3:49-61.

7. Russo J, Hasan Lareef M, Balogh G, Guo S, Russo $\mathbb{H}$ : Estrogen and its metabolites are carcinogenic agents in human breast epithelial cells. J Steroid Biochem Mol Biol 2003, 87:1-25.

8. Nguyen BL, Chetrite G, Pasqualini JR: Transformation of estrone and estradiol in hormone-dependent and hormone-independent human breast cancer cells. Effects of the antiestrogen ICI 164,384, danazol, and promegestone (R-5020). Breast Cancer Res Treat 1995, 34:139-146.

9. Pasqualini JR: The selective estrogen enzyme modulators in breast cancer: a review. Biochim Biophys Acta 2004, 1654:123-143.

10. Aka JA, Mazumdar M, Lin S-X: Reductive 17beta-hydroxysteroid dehydrogenases in the sulfatase pathway: critical in the cell proliferation of breast cancer. Mol Cell Endocrinol 2009, 301:183-190.

11. Aka JA, Mazumdar M, Chen C-Q, Poirier D, Lin S-X: 17ß-hydroxysteroid dehydrogenase Type 1 stimulates breast cancer by dihydrotestosterone inactivation in addition to estradiol production. Mol Endocrinol 2010, 24:832-845.

12. Oduwole OO, Li Y, Isomaa $W$, Mäntyniemi A, Pulkka AE, Soini $Y$, Vihko PT: 17beta-hydroxysteroid dehydrogenase type 1 is an independent prognostic marker in breast cancer. Cancer Res 2004, 64:7604-7609.

13. Gunnarsson C, Jerevall PL, Hammar K, Olsson B, Nordenskjöld B, Jansson A Stål O: Amplification of HSD17B1 has prognostic significance in postmenopausal breast cancer. Breast Cancer Res Treat 2008, 108:35-41.

14. Meier M, Möller G, Adamski J: Perspectives in understanding the role of human 17beta-hydroxysteroid dehydrogenases in health and disease. Ann N Y Acad Sci 2009, 1155:15-24.

15. Laplante $Y$, Rancourt C, Poirier D: Relative involvement of three 17betahydroxysteroid dehydrogenases (types 1, 7 and 12) in the formation of estradiol in various breast cancer cell lines using selective inhibitors. Mol Cell Endocrinol 2009, 301:146-153.

16. Shevchenko A, Wilm M, Vorm O, Mann M: Mass spectrometric sequencing of proteins from silver-stained polyacrylamide gels. Analytical Chemistry 1996, 68:850-858.

17. Havlis J, Thomas H, Sebela M, Shevchenko A: Fast-Response Proteomics by Accelerated In-Gel Digestion of Proteins. Anal Chem 2003, 75:1300-1306.

18. Luu-The V, Paquet N, Calvo E, Cumps J: Improved real-time RT-PCR method for high-throughput measurements using second derivative calculation and double correction. Biotechniques 2005, 38:287-293.

19. UniProt database. [http://www.uniprot.org].
20. Huber M, Bahr I, Krätzschmar J R, Becker A, Müller E C, et al: Comparison of Proteomic and Genomic Analyses of the Human Breast Cancer Cell Line T47D and the Antiestrogen-resistant Derivative T47D-r. Mo Cell Proteomics 2004, 3:43-55.

21. Gygi SP, Rochon Y, Franza BR, Aebersold R: Correlation between Protein and mRNA Abundance in Yeast. Mol Cell Biol 1999, 19:1720-1730.

22. Aka JA, Lin S-X: Comparison of functional proteomic analyses of human breast cancer cell lines T47D and MCF7. PLOS ONE 2012, 7(2):e31532.

23. Kim J, Petz LN, Ziegler YS, Wood JR, Potthoff SJ, Nardulli AM: Regulation of the estrogen-responsive pS2 gene in MCF-7 human breast cancer cells. $J$ Steroid Biochem Mol Biol 2000, 74:157-168.

24. Marchiori AC, Casolari DA, Nagai MA: Transcriptional up-regulation of PHLDA1 by 17 beta-estradiol in MCF-7 breast cancer cells. Braz J Med Biol Res 2008, 41:579-582.

25. Hevir N, Trošt N, Debeljak N, Rižner TL: Expression of estrogen and progesterone receptors and estrogen metabolizing enzymes in different breast cancer cell lines. Chem Biol Interact 2011, 191:206-216.

26. Smuc T, Rizner TL: Expression of 17beta-hydroxysteroid dehydrogenases and other estrogen-metabolizing enzymes in different cancer cell lines. Chem Biol Interact 2009, 178:228-33.

27. Curtis CD, Likhite VS, McLeod IX, Yates JR, Nardulli AM: Interaction of the tumor metastasis suppressor nonmetastatic protein 23 homologue $\mathrm{H} 1$ and estrogen receptor alpha alters estrogen-responsive gene expression. Cancer Res 2007, 67:10600-10607.

28. Charpentier AH, Bednarek AK, Daniel RL, Hawkins KA, Laflin KJ, Gaddis S, MacLeod MC, Aldaz CM: Effects of estrogen on global gene expression: identification of novel targets of estrogen action. Cancer Res 2000, 60:5977-5983.

29. Lin KH, Wang WJ, Wu YH, Cheng SY: Activation of Antimetastatic Nm23$\mathrm{H} 1$ Gene Expression by Estrogen and Its alpha-Receptor. Endocrinology 2002, 143:467-475

30. Wang DY, Fulthorpe R, Liss SN, Edwards EA: Identification of estrogenresponsive genes by complementary deoxyribonucleic acid microarray and characterization of a novel early estrogen-induced gene: EEIG1. Mol Endocrinol 2004, 18:402-411.

31. Liaudet-Coopman E, Beaujouin M, Deroca D, Garcia M, Glondu-Lassis M Laurent-Matha V, Prébois C, Rochefort H, Vignon F: Cathepsin D: newly discovered functions of a long-standing aspartic protease in cancer and apoptosis. Cancer Lett 2006, 237:167-179.

32. Flørenes VA, Aamdal S, Myklebost O, Maelandsmo GM, Bruland OS, Fodstad O: Levels of nm23 messenger RNA in metastatic malignant melanomas: inverse correlation to disease progression. Cancer Res 1992, 52:6088-6091.

33. Youn B, Kim HD, Kim J: Nm23-H1/nucleoside diphosphate kinase as a key molecule in breast tumor angiogenesis. Expert Opin Ther Targets 2008, 12:1419-30.

34. Boissan M, De Wever $O$, Lizarraga F, Wendum D, Poincloux R, Chignard N, Desbois-Mouthon C, Dufour S, Nawrocki-Raby B, Birembaut P, Bracke M, Chavrier P, Gespach C, Lacombe ML: Implication of metastasis suppressor $\mathrm{NM} 23-\mathrm{H} 1$ in maintaining adherens junctions and limiting the invasive potential of human cancer cells. Cancer Res 2010, 70:7710-7722.

35. Miyoshi Y, Ando A, Hasegawa S, Ishitobi M, Tamaki Y, Noguchi S: High expression of steroid sulfatase mRNA predicts poor prognosis in patients with estrogen receptor-positive breast cancer. Clin Cancer Res 2003, 9:2288-2293.

36. Irahara N, Miyoshi Y, Taguchi T, Tamaki Y, Noguchi S: Quantitative analysis of aromatase, sulfatase and 17beta-HSD(1) mRNA expression in soft tissue metastases of breast cancer. Cancer Lett 2006, 243:23-31.

37. Salhab M, Reed MJ, Al Sarakbi W, Jiang WG, Mokbel K: The role of aromatase and 17-beta-hydroxysteroid dehydrogenase type 1 mRNA expression in predicting the clinical outcome of human breast cancer. Breast Cancer Res Treat 2006, 99:155-162.

38. Mindnich $\mathrm{R}$, Adamski J: Zebrafish 17beta-hydroxysteroid dehydrogenases: an evolutionary perspective. Mol Cell Endocrinol 2009, 301:20-26.

39. Poirier D, Mazumdar M, Lin S-X: Design and synthesis of bisubstrate inhibitors of type $117 \beta$-hydroxysteroid dehydrogenase: Overview and perspectives. Eur J Med Chem 2008, 43:2298-2306.

40. Zhang C-Y, Chen J, Yin D-C, Lin S-X: The contribution of 17betahydsroxysteroid dehydrogenase type 1 to estrtadiol-estrone ration in breast cancer cells. PLOS ONE 2012, 7(1):e29835. 
doi:10.1186/bcr3207

Cite this article as: Aka et al: 17beta-hydroxysteroid dehydrogenase

type 1 modulates breast cancer protein profile and impacts cell

migration. Breast Cancer Research 2012 14:R92.

Submit your next manuscript to BioMed Central and take full advantage of:

- Convenient online submission

- Thorough peer review

- No space constraints or color figure charges

- Immediate publication on acceptance

- Inclusion in PubMed, CAS, Scopus and Google Scholar

- Research which is freely available for redistribution

Submit your manuscript at 